\title{
READY OR NOT?
}

\author{
AN INTERNATIONAL STUDY OF THE \\ PREPARATION OF EDUCATIONAL DEVELOPERS
}

Nancy Van Note Chism, Indiana University School of Education,
Indiana University-Purdue University Indianapolis

This report of an international survey of educational developers describes their entry-level background knowledge and skills for the work of educational development, how they obtained them, and their recommendations on helping prepare new entrants to the profession. Respondents reported that their experiences rendered them moderately prepared for some tasks and less prepared for others, notably consultation. The results can inform increased professionalization of educational development through more systematic preparation of future educational developers.

Educational developers in higher education settings frequently observe that most faculty members are not prepared to teach in any formal or extensive way. What they fail to add is that the same is true for their own profession. The findings reported here document the preparation experiences of entrants to educational development, their assessment of its quality, and their recommendations for the preparation of future entrants.

\section{Conceptual Framework}

Literature on the professions consistently names the existence of formal career preparation and an established body of knowledge as requisite characteristics of professions. In addressing the need for formal preparation

\footnotetext{
My appreciation is expressed to Mellisa Benites Cotera, and to Josh Smith and staff members Jake Stuckey and Eileen Turpin of the IUPUI Center for Urban and Multicultural Education for their help.
} 
of educational developers, Baume (2004) cites the work of many scholars of professionalism, the most well known of whom is Wilensky (1964), whose classic list of characteristics of a profession explicitly identifies emphasis on formal training as a key attribute of a profession. The "systematic preparation and training of practitioners" is also on Knapper's (1998, p. 93) list of hallmarks of a profession.

The association of professions with established bodies of knowledge is also supported by the literature on professionalism, summarized by the observation of Eraut (1994): “The power and status of professional workers depend to a significant extent on their claims to unique forms of expertise, which are not shared with other occupational groups, and the value placed on that expertise" (p. 14). In his conception, Eraut indicates that at certain points in their identity, groups of people performing an activity make conscious efforts to portray themselves as professionals.

The literature on professions also portrays a pattern of advancement from craft knowledge transmitted largely through the interactions of practitioners and their apprentices to more abstract, organized knowledge bases learned through more formal methods, such as classroom instruction, most often coupled with internships or other forms of experiential learning, overseen by a mentor. Examples include medicine, law, social work, and precollegiate teaching. Becher and Trowler Becher (2001) describe this process in academia. Transitions between stages of development within a profession are often characterized by intense debate between those who seek to formalize the preparation of new professionals and those who favor the existing informal system.

It is within this framework of professional knowledge that this study is situated. The study sought to understand the status of the professionalization of the field of educational development and practitioners' views on the nature of the knowledge base they need and how it is acquired.

\section{Literature Review}

Educational developers are part of a relatively new group of practitioners who are still struggling with defining the boundaries of their work. Identity literature is common and portrays differences between and across institutions and countries as to what educational developers do. Clement and McAlpine (2008) call educational development an "emerging" field, without a common body of knowledge, "let alone a shared set of convictions or research methods" (p. 1). Carew, Lefoe, Bell, and Armour (2008) speculate that the work is best described as an "elastic practice," whose practitioners rely on "the tailoring of an approach for a specific context, drawing on the toolkit of techniques, experiences, ideas, and theoretical 
stances that a particular academic developer has collected" (p. 60). The positive side of identity struggles, Grant (2007) points out, is that ambiguous status avoids issues of exclusion, boundary patrolling, and adoption of codified rules of practice.

At the same time, there is concern with preparing new educational developers, particularly as the first generation of developers ages. Over time, practitioners have discussed extensively the knowledge and skills that developers should have (Baume \& Kahn, 2004; Bergquist \& Phillips, 1995; Brinko \& Menges, 1997; Gillespie, Hilsen, \& Wadsworth, 2002; Isaacs, 1997; Kahn, 2004; Kahn \& Baume, 2003; Knapper \& Piccinin, 1999; Lewis, 1988; Outram, 2006; Paulsen \& Feldman, 1995). There is also a small literature on how educational developers say they have learned their profession (Fraser, 1999; Graf \& Wheeler, 1996; Sorcinelli, Austin, Eddy, \& Beach, 2006).

Rowland (2003), comparing teaching and educational development, asks whether educational development is atheoretical (requiring simply a practical feel for what is involved) or theory based (working from an articulated base of ideas about relationships between phenomena). He concludes that both the practical and theoretical are helpful, yet acknowledges the tensions of this middle space. Others such as Kahn (2004) point out that the knowledge bases of teaching and educational development overlap, but "work that involves enhancing a specialist practice will also draw on skills that will not necessarily be developed by simply engaging in the practice itself" (p . 214).

Although such distinctions are drawn between learning to teach and learning the practice of educational development, insights about the nature of experiential learning (Kolb, 1984) and reflective practice (Moon, 1999; Schön, 1983) in learning to teach generally continue to be applied to the development of professional knowledge (Sharp, 2004). The focus is on individual cycles of growth rooted in inquiry into practice and situated within a community of practice.

This study rests on the assumption that although identity issues remain, the existence of the term educational developer.(or professional developer, faculty developer, or academic developer) and the expansion of centers for development and professional associations for educational developers worldwide indicate that a core conceptualization of this work has formed, even though its nature is dependent on context, and that consensus on boundary issues is still elusive. This chapter provides a descriptive portrait of what preparation a sample of current educational developers had on entry to their roles, how they evaluated the quality of that preparation, and the types of preparation they would recommend for new developers. 


\section{Study Design}

The support of a grant from the Professional and Organizational Development Network in Higher Education (POD) enabled this project to be conducted on an international level, affording the opportunity to gather data across national boundaries. Although the context of educational development varies across and within nations, the focus of the study was on ascertaining commonalities while not denying differences. A "maximum variation" sample (Patton, 2002) was thus favored. Methods are described in greater detail in the study report (Chism, 2008) and included a presurvey to ground the categories for the final survey, circulation of drafts of the survey to the heads of major educational development associations for review and subsequent revision, and administration of the survey through the distribution channels of these associations. The final draft of the survey contained items about informed consent and appropriateness of the survey for the respondents, as well as items about their backgrounds, work experiences, and recommendations for the preparation of future developers. A five-point scale was used for the items. An electronic survey format was used, and the survey instrument was available in both English and French. Survey instruments are appended to the formal report (Chism, 2008).

The 565 usable responses came from respondents in over twenty countries and were diverse in demographic makeup and career experience. The majority were female (70 percent) and worked in English-speaking countries-the United States ( 57 percent), Canada (11 percent), the United Kingdom (13 percent), and Australia/New Zealand (6 percent)-which constituted all but 13 percent of the sample. Most of the participating organizations were unable to provide population characteristics of their lists, a limitation that precluded calculation of a response rate and other demographic indicators. Thus, the emphasis here is on broad patterns and text comments.

\section{Prior Work Experiences}

A majority of the developers (67 percent) held faculty positions before entry to the profession. Some worked in central academic support units as directors ( 5 percent) or staff ( 15 percent), and others came from central administrative officer positions (6 percent). It is interesting to note that 10 percent had no previous higher education experience. Text comments indicate that these members of the profession came from secondary school positions, corporate training, or other venues. 
A little more than half ( 57 percent) of respondents indicated that they entered the profession as a staff member of an educational development unit, and another 21 percent said that they had informal responsibilities for development. Over a quarter of respondents ( 26 percent) came into the profession as director of an educational development unit without having had any prior experience as a staff member. This was particularly so for American and Canadian developers, for whom the percentage of respondents indicating entry position as director (36 percent and 25 percent, respectively) was significantly higher than Australian (6 percent) and U.K. ( 9 percent) developers. One reason might be that it is relatively common in the United States to have development units staffed by only one professional or to use committees or appointments within other units to deliver educational development services. Sorcinelli et al. (2006) report that only 54 percent of the U.S. campuses in their survey have centralized units with dedicated staff.

Most of the respondents held advanced degrees, with 60 percent reporting doctorates and 35 percent master's degrees. No differences in gender representation across degree categories were found, but a significant country difference was found in the higher percentage of doctorates reported by U.S. developers than those from other countries. About 74 percent of U.S. respondents reported having doctorates, compared with 52 percent from Australia and New Zealand, 41 percent from the United Kingdom, 39 percent from Europe, and 36 percent from Canada.

Education was named as the major area of study for respondents' most advanced degree (48 percent). Australian respondents reported the highest percentage of education degrees ( 70 percent), followed by Canada (64 percent). The percentage in the United Kingdom and the United States was virtually the same, at 44 percent, while Europeans reported 39 percent.

\section{Content Knowledge}

With respect to content knowledge, respondents reported having gained their entry-level knowledge through various activities. The most frequently cited activity was reading, followed by conferences and workshops on teaching and learning. Conferences and workshops on educational development and formal course work were rated lowest of the choices provided on the survey item. Those who answered "other" for this item indicated that teaching in secondary school, working as a graduate teaching assistant, or having had a mentor or having worked in 
corporate training gave them content knowledge for educational development work.

When they were asked to evaluate the effectiveness of their content knowledge experiences for their subsequent work as a developer, respondents generally claimed moderate effectiveness for formal course work and conferences and reading books and articles, and less effectiveness for participation in listservs and online communities.

Respondents rated their entry-level content knowledge as a result of these experiences by indicating that they were somewhat prepared, with average ratings between "some knowledge" and "moderate knowledge" ( 3 and 4 on a five-point scale) for items about student assessment, instructional design, use of information technology, and evaluation of teaching. They assigned their lowest average rating to knowledge of theories of organizational change (3.13) and faculty development (3.05) and multicultural teaching (3.13) and their highest to knowledge of learning theory (3.90) and active learning strategies (3.99).

\section{Skills Background}

With respect to activities that provided skills that educational developers needed, the respondents reported that they engaged in apprenticeships and formal course work, as well as participating in administrative or faculty experiences before working in educational development. They listed additional activities as well: experiences as secondary teachers or graduate teaching assistants, experiences as staff developers in primary or secondary settings, work as instructional technology consultants, and experiences outside education, such as corporate training or project management. Some respondents felt that skills learned through specific experiences were transferable to the work of educational development, such as the one who listed "childbirth education and assertiveness training" and another who listed army service as preparation experiences.

When respondents were asked to evaluate the potential effectiveness of these experiences for providing educational developers with the skills they need, they rated educational apprenticeships and formal course work most highly, with background work experiences as faculty members, directors of other units, and advisory board members next in potential effectiveness.

Based on these prior experiences, respondents rated their entry-level skills on such tasks as supervising staff, preparing conference proposals or publications, event planning, and conflict management from "very little skill" to "some skill" ( 3 to 4 on a five-point scale), except for the category 
of presenting work at workshops or conferences, for which they rated themselves as having moderate skill (4.07). The lowest-rated areas were in the categories of performing research or organizational consultations $(2.57$ and 2.52 , respectively), writing grant proposals (2.73), performing teaching consultations (3.08), managing a budget (3.05), and performing program assessments (3.09).

A strong theme in the comments throughout the survey, and especially in the skills section, was concern with the question of whether faculty experience is necessary for the preparation of educational developers. For the most part, those who promote faculty experience or status couch their arguments around issues of respect and credibility rather than the actual skills one acquires as a faculty member. One U.S. respondent stated, "It is critical for educational developers to have experience as a faculty member before attempting to influence faculty members as an educational developer." A respondent from the United Kingdom stated, "It seems to me that the most vital thing is that educational development isn't seen as an alternative career route (or career death) and that educational development professionals continue to be academics (or faculty as you say in the U.S.) with the same expectations for scholarship and teaching, otherwise it becomes increasingly hard to relate to academic colleagues." A U.S. respondent, rather than focusing on credibility, spoke to the depth of skills built during a faculty career: "New faculty developers should come from the faculty. Teaching course design, active learning techniques, etc. can be done by nonfaculty, but it reduces teaching to a 'bag of tricks' rather than a philosophy, values, and vocation."

In contrast, several U.S. respondents argued that faculty experience alone is not sufficient preparation for educational development careersfor example:

I believe professional development for faculty is a field that must be more clearly understood in higher education. It is a field that requires special training, scholarship, and experience. Too often it seems to be regarded as something that "anyone can do," especially faculty since they teach. I strongly disagree with that philosophy. This field demands its own expertise and scholarship in many areas such as organizational development, teaching and learning, assessment, learning theory, and communication.

Another respondent said, "Educational development needs to be seen as its own discipline. Being a good teacher and a successful faculty member are helpful but not the skill set needed for someone who is more of a coach than a player." 
Some respondents isolated teaching experience, rather than having had a faculty appointment, as important preparation for educational developers. While some focused on the credibility argument, others focused more on the understanding and compassion that an experienced teacher can bring to the work. A U.S. respondent stated, "I believe teaching experience in higher education is an important prerequisite for an educational developer. This is because it is important to be able to empathize with faculty when they express their varied concerns about teaching in higher education. In addition to empathy, it is important to provide options for faculty as they deal with the myriad duties, responsibilities, concerns."

A U.K. respondent added, "It is vital that educational developers have had experience and have the credentials as having been-or continuing to be-highly effective teachers in higher education. Without this any other qualification or training is not going to help win over faculty."

\section{Recommendations for Preparation of Future Developers}

The final section of the survey asked respondents to go beyond their own personal experiences and provide their recommendation on the potential efficacy of several methods for preparing future educational development professionals, as well as their ratings of the importance of content knowledge topics and skills that future professionals should possess. Respondents favored apprenticeships as the most effective way to prepare future professionals, yet they also expressed strong support for formal course work as part of a degree or specialist program and conference workshops or short courses on educational development. They expressed somewhat less support for Web-based tutorials but still saw some potential in them.

Survey responses documented respondents' opinions on the importance of the specific knowledge and skill areas listed on the survey instrument for the preparation of professionals. Respondents' ratings on the relative value of content knowledge topics recommended for inclusion in preparation experiences for new educational developers were ranked between "moderately important" and "very important" (4 to 5 on a five-point scale). Having knowledge of multicultural teaching received the highest mean (4.72), with evaluation of teaching (4.68), student assessment approaches (4.67), and instructional design (4.65) following closely. Ratings of various skills that respondents thought educational developers should acquire were ranked from somewhat to very important ( 3 to 5 on a five-point scale), with highest mean ratings going to oral presentation 
skills (4.63), followed by consultation techniques (4.48), program administration (4.01), and conflict resolution skills (4.03).

\section{Discussion}

The results of this study support and add specificity to anecdotal reports that portray a rather unplanned entry to careers in educational development. They echo the findings of Fraser (1999), McDonald and Stockley (2008), and Kahn (2004) about entry to the profession. While most of the developers surveyed came from other positions within higher education settings, few listed any specific formal preparation for the work of development. Through their experience, most were familiar with the context of colleges and universities and with the work of faculty members. A moderate number of new entrants had been exposed to teaching and learning issues through having served as faculty members or through reading and workshop attendance, yet fewer than half had attended conferences, workshops, or courses on educational development. Fewer than a third reported having special preparation in the consultation skills that educational developers use. As a result, the majority indicated that they lacked specific educational development content knowledge and skills upon entry. Clearly there is a steep learning curve for new developers, one that takes place on the job. In recommending experiences for new developers, the respondents expressed strong support for apprenticeships and formal course work in educational development, as well as reading on educational development and conference or workshop attendance.

Based on the framework for this study, the results indicate that if formal preparation experiences are a hallmark of professions, the field of educational development is still in a formative period. They also indicate that although more and more developers (such as Eggins \& MacDonald, 2003; Felten, Kalish, Pingree, \& Plank, 2007; Wilcox, 2009) are pointing to a scholarship of educational development, it is not being systematically accessed by those preparing to enter the field. (See Chapter Twenty-One, this volume, for a discussion of the state of the scholarship of educational development.) Brew and Pesata (2008) concur: "So it is not uncommon for senior managers to believe that any university teacher who has taught students in a faculty is capable of turning into an effective academic developer overnight without any kind of mentorship, training or understanding of the body of literature that informs academic development scholarship and practice" (p. 85).

Kahn (2004) points out that it is not uncommon for developers to work concurrently in fields that require three knowledge bases: initial 
discipline, teaching of that discipline, and educational development. Because its practitioners often come to educational development as a second profession after having served in another position, most have not undertaken specialized academic course work or apprenticeships in the field. It is unlikely that they will return to graduate school to prepare for this new career, yet there may be alternatives that are more systematic and perhaps more efficient than the trial-and-error learning that now occurs. For both those who are entering educational development as a first career and those coming from other career paths, much might be gained through studying the theoretical frameworks and research literature informing educational development through entry-level programs, delivered online or at institutes. Skills used in educational development might be honed through apprenticeships at nearby institutions or through an overlap period with their predecessors, overseen by experienced developers who can serve as mentors. These opportunities can be added to the informal methods now available, such as reading and conference attendance, resulting in a more intentional preparation experience for new developers. Cowan (2004) cautions that experience alone is not a sufficient base for learning the practice of educational development: he recommends that reflective inquiry on practice, guided by an experienced developer, must be a hallmark of such approaches.

Professional associations should be called on to take the lead in organizing preparation experiences. This effort will enable the benefits that more effective practitioners can produce at their home institutions and lead to greater professionalization of the field. When practice moves from idiosyncratic to theory based, from personally invented to informed by past study, the field as a whole advances. This argument does not preclude individual creativity or indicate absolute formulas for good practice, but it does underscore that there is now foundational knowledge that educational developers should have. Several associations have already developed initiatives for the preparation of new entrants to the field. Increased formal activity within educational developers' professional associations, such as the certificate programs offered by the Staff and Educational Development Association in the United Kingdom and the POD-sponsored International Institute for New Faculty Developers, may be seen as evidence of growing activity in providing these preparation experiences. More of these initiatives are needed. It is no longer acceptable for centers to appoint directors without substantial knowledge of the field or expect that those with only teaching experience or a faculty title can automatically move into development positions without further preparation. 
Interest in establishing and codifying an established knowledge base is supported, as noted above, by current discussion of the scholarship of educational development. Gosling (2007) speaks of the "academicisation" of educational development, arising in response to charges that existing approaches lack a theory base. He indicates that in the United Kingdom, 72.5 percent of educational development units now see contributing to scholarship as an essential part of their mission and that 67.5 percent believe that they must sponsor others' work in the scholarship of teaching and learning. Stefani (2004) optimistically observes that the foundations of the profession are being established: "Formal organization and structure is becoming more evident, with an increasing range of recognized networks involved in promoting and disseminating current scholarship, and research relating to different aspects of academic practice and development" (p. 21).

In addition to welcoming and using scholarship on educational development, additional studies of the efficacy of methods for preparing new developers are needed. Increasing understanding of the skills and knowledge bases needed for the various tasks of the educational developer and how these are best acquired is crucial to the continued maturation of the profession. Without intentional cultivation of the scholarly and practical foundations for practice, the field is doomed to amateur status and uneven efficacy.

As colleges and universities around the world undertake reforms aimed at modernizing and responding to new global imperatives, they need the guidance of educational developers more than ever before. Already those in the field are indicating that filling positions in educational development with prepared individuals has become increasingly challenging (McDonald \& Stockley, 2008).

Is the field now mature enough to invest in more formal preparation of educational developers? Are developers ready to state that theirs is a profession that relies on specialized knowledge that new entrants must have? The answer may lie in future new significant and thoughtful preparation vehicles.

\section{REFERENCES}

Baume, D. (2004, June). Professional development, professional recognition and professional standards for higher education teachers and developers. Paper presented at the annual meeting of the International Consortium on Educational Development, Ottawa.

Baume, D., \& Kahn, P. (Eds.). (2004). Enhancing staff and educational development. London: RoutledgeFalmer. 
Becher, T., \& Trowler Becher, P. (2001). Academic tribes and territories: Intellectual enquiry and the cultures of disciplines (2nd ed.). Buckingham, UK: Society for Research into Higher Education and Open University Press.

Bergquist, W., \& Phillips, S. (1995). Developing human and organizational resources: A comprehensive manual. Point Arena, CA: Peter Magnusson Press.

Brew, A., \& Pesata, T. (2008). The precarious existence of the academic development unit. International Journal for Academic Development, 13(2), 83-85.

Brinko, K. T., \& Menges, R. J. (Eds.). (1997). Practically speaking: A sourcebook for instructional consultants in bigher education. Stillwater, OK: New Forums Press.

Carew, A., Lefoe, G., Bell, M., \& Armour, L. (2008). Elastic practice in academic developers. International Journal for Academic Development, 13(1), 51-66.

Chism, N.V.N. (2008). A professional priority: Preparing educational developers. Indianapolis: Indiana University School of Education, IUPUI. Retrieved from http://ctl.iupui.edu/common/uploads/library/ CTL/CTL605522.doc

Clement, M., \& McAlpine, L. (2008). In search of a paradigm: The sequel. International Journal for Academic Development, 13(1), 1-3.

Cowan, J. (2004). Learning from experience. In D. Baume \& P. Kahn (Eds.), Enhancing staff and educational development (pp. 192-211). London: RoutledgeFalmer.

Eggins, H., \& MacDonald, R. (2003). The scholarship of academic development. Buckingham, UK: Open University Press.

Eraut, M. (1994). Developing professional knowledge and competence. London: Routledge.

Felten, P., Kalish, A., Pingree, A., \& Plank, K. M. (2007). Toward a scholarship of teaching and learning in educational development. In D. R. Robertson \& L. B. Nilson (Eds.), To improve the academy, Vol. 25. Resources for faculty, instructional, and organizational development (pp. 93-108). San Francisco: Jossey-Bass.

Fraser, K. (1999). Australasian academic developers: Entry into the profession and our own professional development. International Journal for Academic Development, 4, 89-101.

Gillespie, K. H., Hilsen, L. R., \& Wadsworth, E. C. (Eds.). (2002). A guide to faculty development: Practical advice, examples, and resources. San Francisco: Jossey-Bass/Anker.

Gosling, D. (2007). Educational development in the United Kingdom: Report to the Heads of Educational Development Group. London: Heads of Development Group. 
Graf, D. L., \& Wheeler, D. (1996). Defining the field: The POD membership survey. Ames, IA: Professional and Organizational Development Network in Higher Education.

Grant, B. M. (2007). The mourning after: Academic development in a time of doubt. International Journal for Academic Development, 12(1), 35-43.

Isaacs, G. (1997). Developing the developers: Some ethical dilemmas in changing times. International Journal for Academic Development, 2(2), 6-12.

Kahn, P. (2004). Developing professional expertise in staff and educational development. In D. Baume \& P. Kahn (Eds.), Enhancing staff and educational development (pp. 212-226). London: RoutledgeFalmer.

Kahn, P., \& Baume, D. (Eds.). (2003). A guide to staff and educational development. London: Kogan Page.

Knapper, C. (1998). Is academic development a profession? International Journal for Academic Development, 3(2), 93-96.

Knapper, C., \& Piccinin, S. (Eds.). (1999). New directions for teaching and learning: No. 79. Using consultants to improve teaching. San Francisco: Jossey-Bass.

Kolb, D. (1984). Experiential learning: Experience as a source of learning and development. Upper Saddle River, NJ: Prentice Hall.

Lewis, K. G. (1988). Face to face: A sourcebook of individual consultation techniques for faculty/instructional developers. Stillwater, OK: New Forums Press.

McDonald, J., \& Stockley, D. (2008). Pathways to the profession of educational development: An international perspective. International Journal for Academic Development, 13(3), 213-218.

Moon, J. (1999). Reflection in learning and professional development: Theory and practice. London: Kogan Page.

Outram, S. (2006). Developing the developer: A Higher Education Academy/ SEDA pilot project. York, UK: Higher Education Academy.

Patton, M. Q. (2002). Qualitative evaluation and research methods (3rd ed.). Thousand Oaks, CA: Sage.

Paulsen, M. B., \& Feldman, K. A. (1995). Taking teaching seriously (ASHE-ERIC Higher Education Report, Vol. 95:2). Washington, DC: George Washington University, Graduate School of Education and Human Development.

Rowland, S. (2003). Academic development: A practical or theoretical business. In H. Eggins \& R. Macdonald (Eds.), The scholarship of academic development (pp. 13-22). Buckingham, UK: Society for Research into Higher Education and Open University Press.

Schön, D. (1983). The reflective practitioner: How professionals think in action. New York: Basic Books. 
Sharp, R. (2004). How do professionals learn and develop? Implications for staff and educational developers. In D. Baume \& P. Kahn (Eds.), Enhancing staff and educational development (pp. 132-153). London:

RoutledgeFalmer.

Sorcinelli, M. D., Austin, A. E., Eddy, P. L., \& Beach, A. L. (2006). Creating the future of faculty development: Learning from the past, understanding the present. San Francisco: Jossey-Bass/Anker.

Stefani, L. (2004). What is staff and educational development? In D. Baume \& P. Kahn (Eds.), Enhancing staff and educational development (pp. 9-23). London: RoutledgeFalmer.

Wilcox, S. (2009). Transformative educational development scholarship: Beginning with ourselves. International Journal for Academic Development, 14(2), 123-132.

Wilensky, H. L. (1964). The professionalization of everyone? American Journal of Sociology, 70(2), 137-158. 